\title{
Description of a New Mangrove Root Dwelling Species of Teleotanais (Crustacea: Peracarida: Tanaidacea) from India, with a Key to Teleotanaidae
}

\author{
Kim Larsen ${ }^{1,3}$, Gobardhan Sahoo ${ }^{2}$ and Zakir Ali Ansari ${ }^{2}$ \\ ${ }^{1}$ CIIMAR (Centro Interdisciplinar de Investigação Marinha e Ambiental), LMCEE \\ (Laboratory for Marine Community Ecology and Evolution), Rua dos Bragas 289, 4050-123 Porto, Portugal \\ E-mail: tanaids@hotmail.com \\ ${ }^{2}$ National Institute of Oceanography (CSIR), Dona Paula, Goa-403004, India \\ ${ }^{3}$ Corresponding author
}

(Received 1 July 2013; Accepted 21 October 2013)

\begin{abstract}
Tanaidaceans collected from mangrove pneumatophores on the west coast of India included females and mancae of a new species of the rare and plesiomorphic family Teleotanaidae, described herein as Teleotanais indiaensisi sp. nov. A key to the species of Teleotanais Lang, 1956 is given. The new species can be distinguished from it two congeners by the following combination of characters: cephalothorax shorter than pereonites 1-3 combined; antennule without pigmentation, distal article incompletely fused with article 4 and with distal and subdistal aesthetascs; fixed finger of cheliped with two ventral, one ventro-subdistal, and four inner setae; uropodal endopod biarticulate.
\end{abstract}

Key Words: Tanaidacea, Tanaidomorpha, Teleotanaidae, Teleotanais, mangrove roots, Goa, India.

\section{Introduction}

In this paper we describe a new tanaidacean species of the suborder Tanaidomorpha from the Indian subcontinent. With a coastline of $7,517 \mathrm{~km}$, records from India of Tanaidacea, or any other smaller marine invertebrates, are remarkably scarce. Only a few tanaidaceans have been recorded from India (Chilton 1924, 1926; Barnard 1935; Balasubrahmanyan 1962; Balasubrahmanian et al. 1979), or from Sri Lanka (Stebbing 1905; Bâcescu 1981; Bamber et al. 1996). With our current knowledge of tanaidacean diversity, occurrence, and distribution elsewhere (Larsen 2005; Tuya et al. 2010), these few records can only be considered a result of low sampling (or identification) effort.

The family Teleotanaidae is a recent construct (Bird and Larsen 2009) and currently consists of only one genus with three species included the one described herein. The family is considered to possess the most plesiomorphic character states within the superfamily Paratanaoidea (Bird and Larsen 2009). It displays plesiomorphic features in the cheliped setation and pigmentation (as in the family Tanaidae) but at the same time shares several features with the family Leptocheliidae in armament of the maxillipedal endite, as well as sharing apomorphic states with Paratanaidae in the pleonite lateral setation and uropods.

\section{Materials and Methods}

All specimens were collected by G. Sahoo from the outer surfaces of pneumatophores [aerial roots] of the Grey Man- grove, Avicennia officinalis Linne scraping with a nylon brush. They were preserved in $90 \%$ ethanol.

The type material is deposited in the Museum Municipal do Funchal (História Natural; MMF), Madeira, Portugal. Body length was measured from the tip of the cephalothorax to the apex of the pleotelson. The terminology in the descriptions is based on Larsen (2003), although the minute terminal article of the antennule is here termed 'terminal cap-like article' (see Larsen et al. 2013). Adjectives such as 'long' and 'short' are used as relative qualifiers with respect of the appendage being described.

Order Tanaidacea Dana, 1849

Suborder Tanaidomorpha Sieg, 1980

Superfamily Paratanaoidea Lang, 1949

Family Teleotanaidae Bamber, 2008

Remarks. The family was erected in Bird and Larsen (2009), but according to the code of nomenclature, authority has to be given to Bamber (2008) who first used a family level name (in this case subfamily).

\section{Genus Teleotanais Lang, 1956}

Revised diagnosis. Female. With mottled dorsal pigmentation. Eye lobes and pigmented eyes present. First four pleonites each bearing pair of articulated, plumose midlateral setae, last pleonite bearing pair of simple midlateral setae. Antenna articles 2 and 3 without dorsodistal spiniform setae, article 3 with proximal, medial, and distal dorsal setae. Maxillule with palp bearing one or two distal setae. Maxillipedal endite not expanded, distally armed with single seta 
and two or three fine, pointed spine. Fixed finger of cheliped with raised inner ridge. Carpus of pereopods 2-3 without spiniform setae. Posterior pereopods with distal spiniform seta on merus, carpus, and propodus; dactylus plus unguis claw-shaped but these elements unfused. Basal articles of pleopods with single dorsal plumose seta. Uropods shorter than pleotelson; exopod with two articles, endopod with one or two articles.

We believe that the presence of a maxillular palp with only one seta in T. warragamba, as recorded by Bamber (2008), is likely to be an artefact as it would otherwise be unique in the Tanaidacea.

Species included: Teleotanais gerlachi Lang, 1956 (type species), T. indiaensis sp. nov., T. warragamba Bamber, 2008.

\section{Teleotanais indiaensis sp. nov. Larsen and Sahoo} (Figs. 1-3)

Material examined. Holotype: non-ovigerous female, $2.2 \mathrm{~mm}$ (Reg. no. MMF42742), Chorao Island, Goa, central west coast of India, 20 February 2011, intertidal. Paratypes (Reg. no MMF42743): one non-ovigerous female (dissected), same locality. Three non-ovigerous females, one manca, same locality; 19 non-ovigerous females, 21 mancae, Diwar Island, Goa, central west coast of India, 25 May 2013, intertidal.

Diagnosis. Cephalothorax shorter than pereonites 1-3 combined. Antennule without pigmentation; distal article incompletely fused with article 4 and bearing distal and subdistal aesthetascs. Fixed finger of cheliped with one subdistal, five inner, and three ventral setae. Uropodal endopod biarticulate.

Description. Female, body from holotype, $2.2 \mathrm{~mm}$, appendages from dissected paratype.

Body (Fig. 1A,B) Slender, more than ten times longer than broad. Unevenly scattered black pigmentation present (similar to that of the Tanaidae genera Tanais and Zeuxo) dorsally on all somites and chelipeds. Cephalothorax subrectangular, 1.2 times as long as wide, shorter than pereonites 1-3 combined, tapering to anterior with slight rostrum. Eye lobes and pigmented eyes present. Pereonite 1 shortest, pereonites 2-5 successively longer. Pereonite 6 longer than pereonite 3 but shorter than pereonite 4 . Each pereonite bearing lateral setae. Pleonites subequal in size, all bearing pleopods, with single pair of articulate plumose midlateral setae on pleonites 1-4 and pair of simple setae on pleonite 5 . Pleotelson semicircular, longer than last two pleonites combined, with two pairs apical setae, the longer of which one is long as uropod.

Antennule (Fig. 1C) shorter than cephalothorax. Article 1 more than twice as long as article 2, shorter than combined length of rest of antennule, with four setulate proximal setae, one simple and three setulate distal setae. Article 21.3 times longer than wide, with one simple medial seta, and two simple and four setulate distal setae. Article 3 almost square, with two simple distal setae. Article 4 incompletely fused with cap-like terminal article, together bearing two subdistal setae and aesthetasc, and four distal setae and aesthetasc.
Antenna (Fig. 1D) marginally shorter than antennule but less than half as thick. Article 1 naked and fused with cephalothorax. Article 2 longer than wide, naked. Article 3 marginally longer than article 4, with one dorsoproximal, one dorsomedial, and two distal setae, one being bayonetshaped. Article 41.25 times as long as article 5, with one long (longer than article 5), one simple, and one setulate distal setae. Article 5 with one long (longer than article 4 ), one simple, and one setulate distal setae. Article $6 \mathrm{~min}$ with one short and three long (longer than articles 4 and 5 combined) terminal setae.

Mouthparts. Labrum (Fig. 1E) with slightly pointed, setulose apex, only weakly demarcated from clypeus. Mandibles with broad, denticulate molar. Left mandible (Fig. 2A) with crenulate lacinia mobilis and incisor. Right mandible (Fig. 2B) without lacinia mobilis, incisor bifurcate, outer margin crenulate. Labium (Fig. 2C) wide, bilobed, inner lobe less than one third as wide as outer lobe, with setulose apex and small outer depression indicating rudiment of palp. Maxillule (Fig. 2D,E) with nine distal spiniform setae and five subdistal setules, palp with two distal setae. Maxilla not recovered. Maxilliped (Fig. 2F) with basis armed with long seta extending beyond end of palp article 2. Endites narrower than bases, with single outer seta, three short, sharp, spiniform distal setae, and rounded inner tubercle. Palp article 1 naked; article 2 with one outer and four inner simple setae. Articles 3 and 4 with eight inner apical setae each. Epignath (Fig. 2G) narrow and naked.

Cheliped (Fig. 3A) with basis as wide as long, bearing dorso-subdistal seta. Merus sub-triangular with two ventral setae. Carpus longer than propodus including fixed finger, with two ventrodistal setae and one small dorsal seta at each end. Propodus robust, with inner row of two shorter setae and one twice as long, with additional seta below dactylus insertion. Fixed finger with two ventral, one ventrosubdistal, and four inner setae, cutting edge expanded into blade-shaped structure. Dactylus with small inner seta.

Pereopod 1 (Fig. 3B) longer than other pereopods, coxa (not illustrated) with seta; basis shorter than three succeeding articles combined, naked. Ischium with one seta. Merus longer than carpus, with single simple ventrodistal seta. Carpus with four simple distal setae. Propodus longer than merus, with six simple distal setae and subdistal dorsal spine. Dactylus and unguis as long as propodus. Dactylus with medial seta, marginally longer than unguis.

Pereopods 2 and 3 (Fig. 3C,D) subequal, shorter and more compact than pereopod 1 . Basis longer than three succeeding articles combined, with two dorsoproximal setulate setae. Ischium with one simple seta. Merus subequal to carpus, with one simple ventrodistal seta. Carpus with three simple ventrodistal setae. Propodus longer than merus, with four simple distal setae and subdistal dorsal spine. Dactylus and unguis combined as long as propodus. Dactylus marginally longer than unguis, former with medial seta,

Pereopods 4 and 5 (Fig. 3E, F) subequal. Basis stout, with one longer setulose ventromedial seta and three shorter setulose dorsoproximal setae. Ischium with two simple setae. Merus marginally longer than carpus, with two ven- 


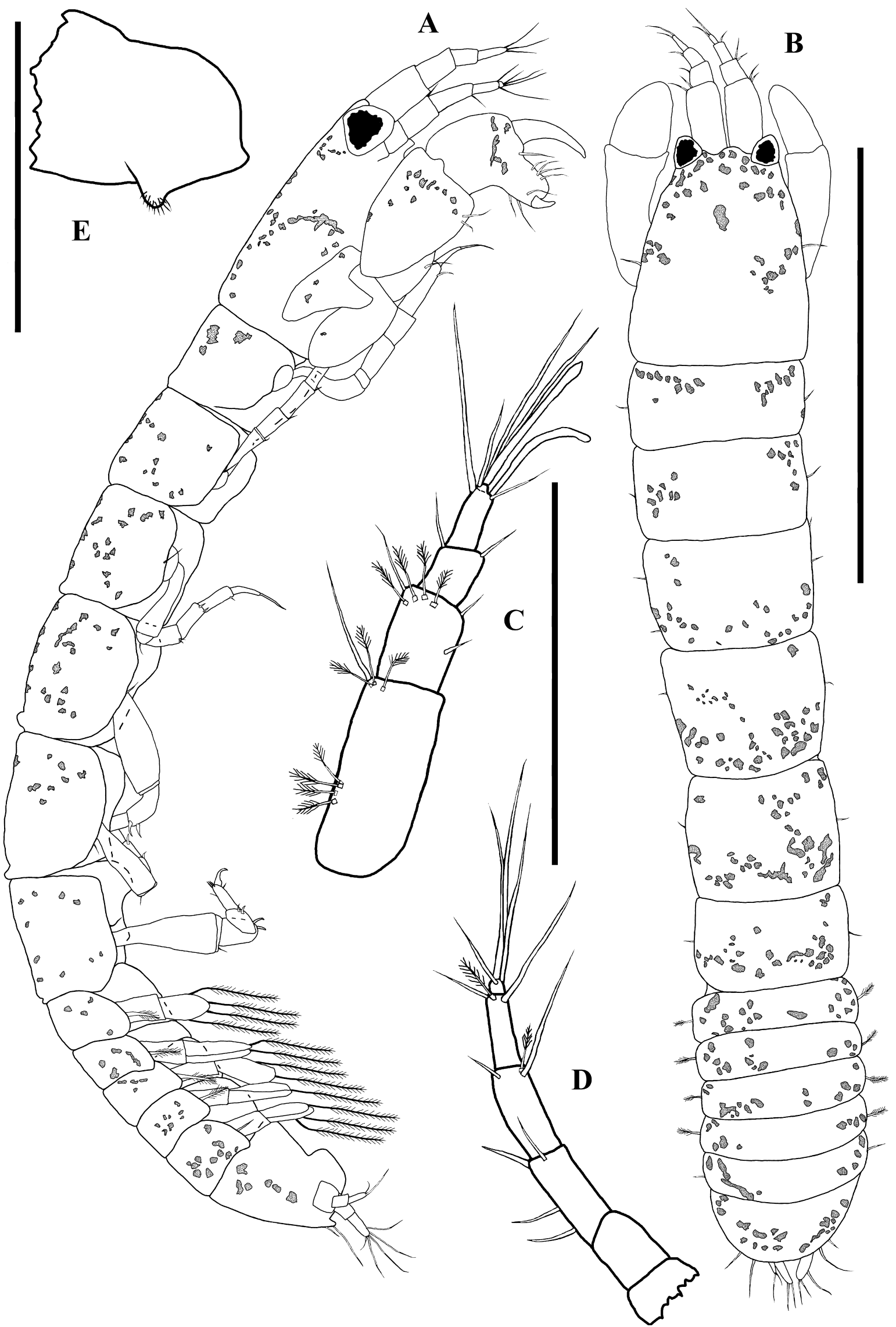

Fig. 1. Teleotanais indiaensis sp. nov. A, holotype, habitus, lateral view; B, paratype, habitus, dorsal view; C, antennule; D, antenna; E, labrum, lateral view. Scale bars: $1.0 \mathrm{~mm}$ for A-B, $0.25 \mathrm{~mm}$ for C-D, $0.1 \mathrm{~mm}$ for E. 


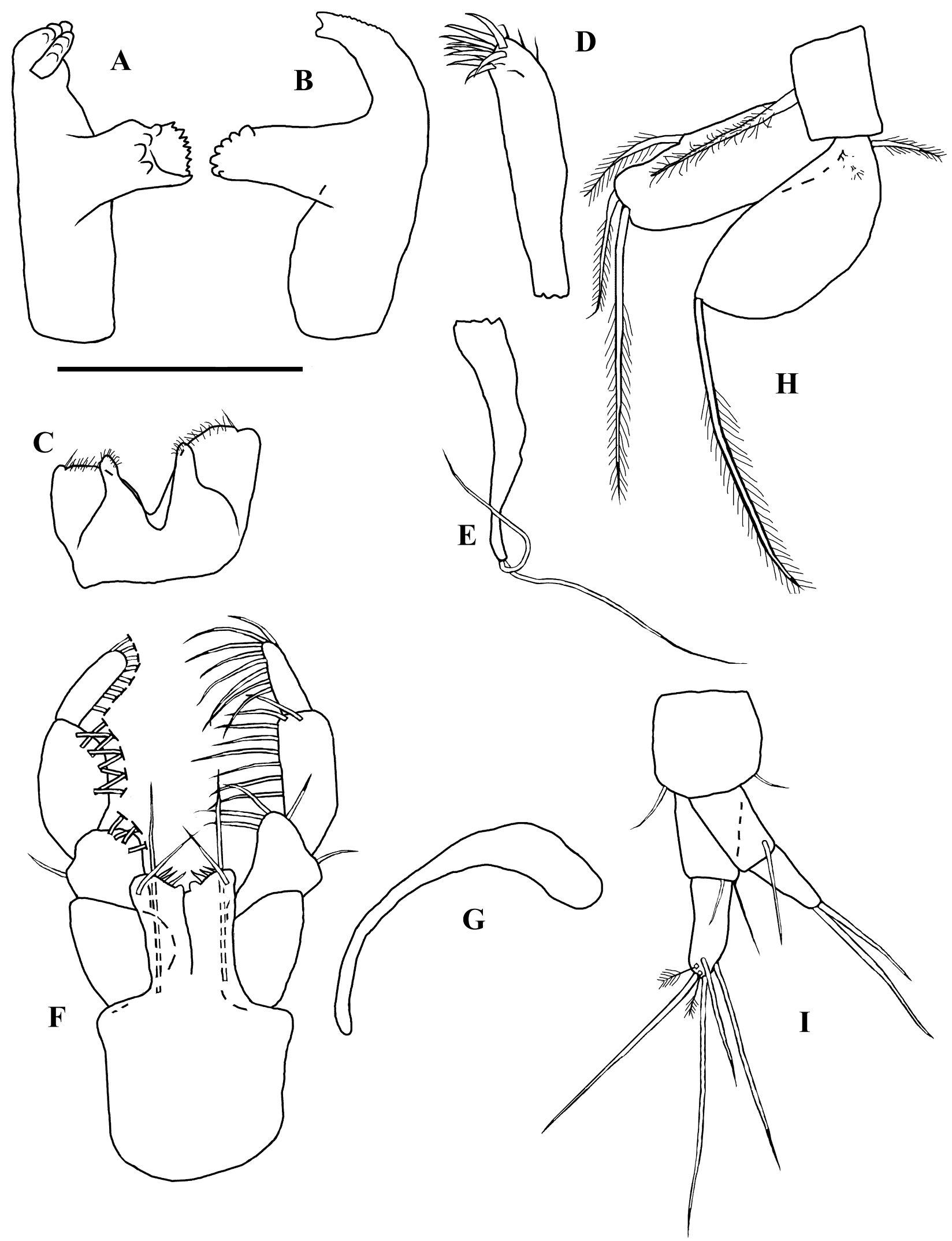

Fig. 2. Teleotanais indiaensis sp. nov. paratype. A, left mandible; B, right mandible; C, labium; D, maxillule, endite; E, same, palp; F, maxilliped; G, epignath; H, pleopod; I, uropod. Scale bars $0.1 \mathrm{~mm}$. 


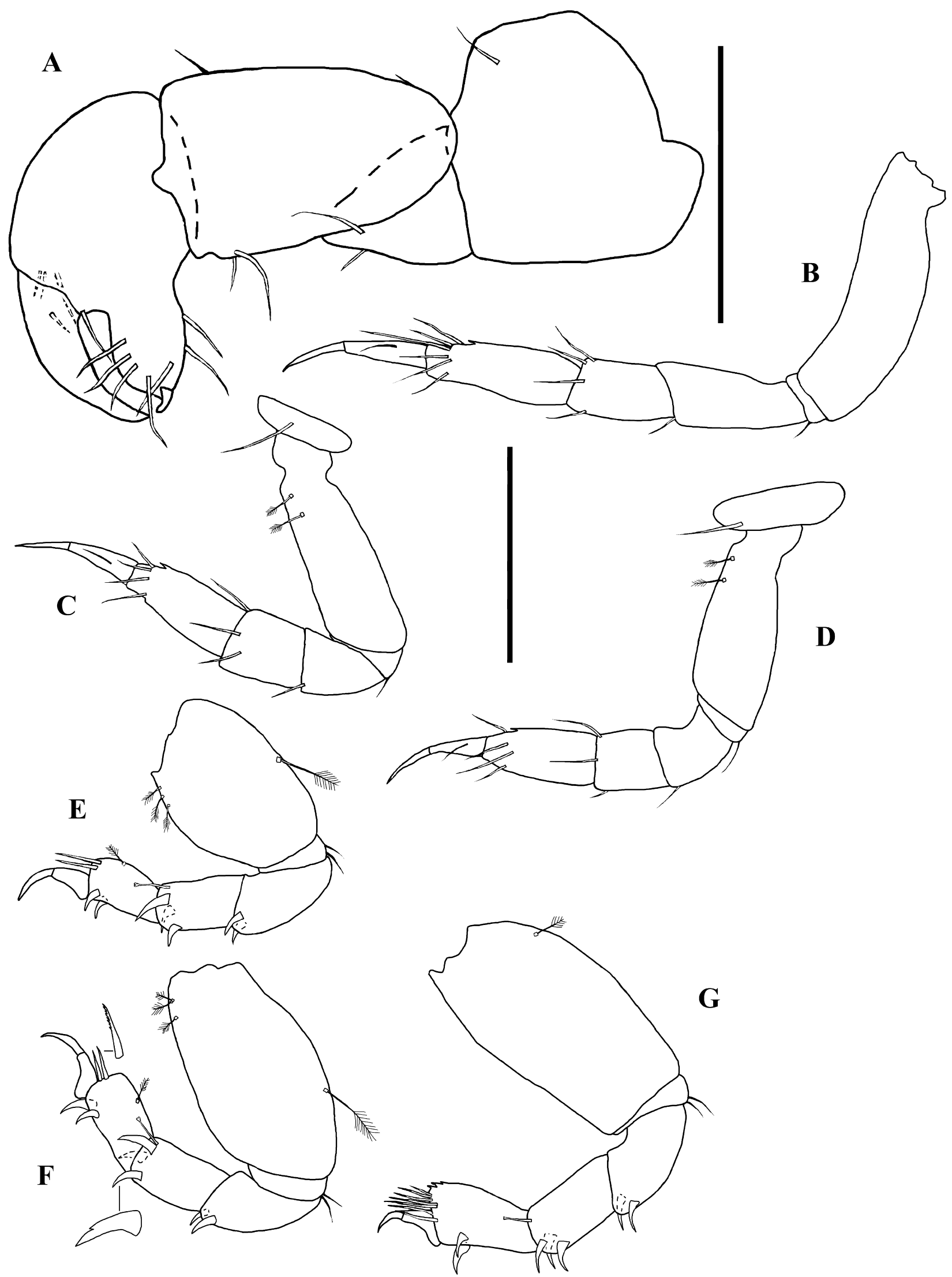

Fig. 3. Teleotanais indiaensis sp. nov. paratype. A, cheliped; B, pereopod 1; C, pereopod 2; D, pereopod 3; E, pereopod 4; F, pereopod 5; G, pereopod 6. Scale bars: $0.25 \mathrm{~mm}$ for A, $0.1 \mathrm{~mm}$ for B-G. 
trodistal spiniform setae. Carpus with three distal spiniform setae and dorsodistal bone-shaped seta. Propodus as long as merus, with two ventrodistal spiniform setae, two dorsodistal distal setae as long as dactylus, and one setulate dorsomedial seta. Dactylus and unguis attached to ventral part of propodus, combined shorter than propodus, claw-shaped but not fused to each other.

Pereopod 6 (Fig. 3G) as pereopods 4 and 5 except basis with one ventroproximal setulose seta and propodus with seven dorsodistal distal setae and three small dorsodistal spines, without dorsomedial setulate seta.

Pleopods (Fig. 2H) with basal article bearing single inner plumose seta. Endopod rectangular, with one inner seta and nine outer setae, most distal is thickest with complex apex. Exopod leaf-shaped, with 18 outer setae.

Uropod (Fig. 2I) marginally longer than half length of pleotelson, its basal article with two small distal setae. Endopod with two articles of subequal length, article 1 with two simple distal setae, article 2 with four long (longer than endopod) simple and two short, setulose setae. Exopod marginally shorter than endopod, with two subequal articles, article 1 with one simple distal seta, article 2 with two long (longer than endopod), thick terminal setae.

Male unknown.

Remarks. The new species differs from the two previously described species of Teleotanais, T. warragamba and T. gerlachi, in the cephalothorax being shorter than pereonites 1-3 combined, the fixed finger of cheliped having two ventral, one ventro-subdistal, and four inner setae, and the uropodal endopod being biarticulate.

Although only three species of this genus have now been recorded, it is already clear that the genus has a cosmopolitan warm water distribution (Brazil, West Atlantic; Florida and El Salvador, Gulf of Mexico; Nigeria, East Atlantic; Australia, Pacific; and now India, Indian Ocean). Cosmopolitan distributions are recorded for a majority of tanaidacean genera (at least those that are not monotypic), and this holds true for both the deep-sea and shallow-water fauna. This fact is a reminder that we still know very little about how these non-swimming animals, which have no dispersal phase, have attained such wide distribution ranges (see Larsen 2005 for review).

Unfortunately, the males of all three species of Teleotanais are currently unknown and this could be an important clue to its phylogenetic position. Lang (1956) found 36 specimens of this genus, Sieg and Heard (1983) obtained twelve from the Gulf of Mexico and more than 200 from Nigeria, and Bamber (2008) reported 19 specimens from Australia. In the present study we recorded more than 40 individuals, and none were of the male gender. If the males were of the feeding type typical of the Tanaidae, it is probable that some would have been found. If the males are of the non-feeding/ non-swimming type typical of Leptocheliidae, the chances of finding them would be smaller but still reasonable, given the many specimens collected. This leads us to suspect that the males of this genus is of the much rarer non-feeding/ swimming type found in the Paratanaidae and Leptognathidae, among others.
Few tanaid records exist from mangrove roots, but this may simply be a reflection of the fact that many ecologists shy away from this group because of the difficulties involved with their identification. This is exemplified by the lack of lower taxon identification seen in many records from mangrove roots habitats, usually only to order (Odum and Heald 1972; Livingston et al. 1977; Nagelkerken and Velde 2004a, 2004b), or in a few cases to family (Corrêa and Uieda 2008). Two notable exceptions are Lang (1956) and Sieg and Heard (1983), which both refer to Teleotanais. Their specimens were also collected from mangrove roots. While members of this genus have also been recorded from other habitats (Lang 1956; Sieg and Heard 1983; Bamber 2008), this genus may have a special affinity to mangrove habitats.

Etymology. Named after the Indian subcontinent.

\section{Key to the genus Teleotanais}

1. Maxillipedal endites with two pointed spiniform setae. Uropodal endopod uniarticulate. Pleopodal endopod with two inner setae .............. T. warragamba (Australia)

- Maxillipedal endites with three pointed spiniform setae. Pleopodal endopod with one inner seta. Uropodal endopod biarticulate.

2. Cephalothorax shorter than pereonites 1-3 combined. Cheliped fixed finger with two ventral, one ventro-subdistal, and four inner setae. T. indiaensis (India)

- Cephalothorax as long as pereonites 1-3 combined. Cheliped fixed finger with one ventral, one ventro-subdistal, and three inner setae. T. gerlachi (Brazil)

\section{Acknowledgments}

KL was funded by the Portuguese Pest-e/MAR/2A0015/ 2011 grant. GS and ZAA are thankful to Director of NIO for providing necessary facilities and to the Deputy Conservator of Forests, Wild Life and Ecotourism, Department of Forests, Goa, for granting permission to carry out research activities at Salim Ali Bird Sanctuary, Chorao Island. We also thank the anonymous reviewers for their constructive comments that improved the manuscript.

\section{References}

Bâcescu, M. 1981. Two new Apseudoidea Leach, 1914 (Crustacea, Tanaidacea) from northern medi-littoral waters of Sri Lanka. Travaux du Muséum d'Histoire Naturelle "Grigore Antipa" 23: 73-80.

Balasubrahmanyan, K. 1962. Apseudidae (Isopoda-Crustacea) from the Vellar Estuary and inshore waters off Porto. Pp 279-285. In: Seshaiya, R. V. (Ed.), Proceedings First All-India Congress of Zoology, 1959. Zoological Society of India, Calcutta.

Balasubramanian, T. C., Lalithambika-Devi, B. and Krishnankutty, M. 1979. Feeding behavior and preying efficiency of Metapenaeus dobsoni. Indian Journal of Marine Science 8(3): 197-200.

Bamber, R. N. 2008. Tanaidaceans (Crustacea: Peracarida: Tanaidacea) 
from Moreton Bay, Queensland. In: Davie, P. J. F. and Phillips, J. A. (Eds.) Proceedings of the Thirteenth International Marine Biological Workshop. The Marine Fauna and Flora of Moreton Bay, Queensland. Memoirs of the Queensland Museum-Nature 54(1): 143-218.

Bamber, R. N., Ariyananda, T. and Silva, E. I. L. 1996. A new genus and species of apseudomorph tanaidacean from Sri Lanka. Asian Marine Biology 13: 133-140.

Barnard, K. H. 1935. Report on the Amphipoda, Isopoda and Tanaidacea in the collection of the Indian Museum. Records of the Indian Museum 37: 279-319.

Bird, G. J. and Larsen, K. 2009. Tanaidacean Phylogeny: The second step. The basal Paratanaoidean families. Arthropod Systematics and Phylogeny 67(2): 137-158.

Chilton, C. 1924. Fauna of the Chilka Lake. Tanaidacea and Isopoda. Memoirs of the Indian Museum 5(12): 875-895.

Chilton, C. 1926. Zoological results of a tour in the Far East. The Tanaidacea and Isopoda of Talé Sap. Records of the Indian Museum 28: $173-188$.

Dana, J. D. 1849. Conspectus Crustaceorum, Conspectus of the Crustacea of the U.S. Exploring Expedition. American Journal of Science 2: 424-428.

Corrêa, M. de O. D. A. and Uieda, V. S. 2008. Composition of the aquatic invertebrate fauna associated to the mangrove vegetation of a coastal river, analyzed through a manipulative experiment. PanAmerican Journal of Aquatic Sciences 3(1): 23-31.

Lang, K. 1949. Contribution to the systematics and synonymies of the Tanaidacea. Arkiv for Zoologi 42(18): 1-14.

Lang, K. 1956. Tanaidacea aus Brasilien, gesammelt von Professor Dr. A. Remane und Dr. S. Gerlach. Kieler Meeresforschungen 12: 249-260.

Larsen, K. 2003. Proposed new standardized anatomical terminology for Tanaidacea (Peracarida). Journal of Crustacean Biology 23(3):
644-661.

Larsen, K. 2005. Deep-Sea Tanaidacea (Crustacea; Peracarida) from the Gulf of Mexico. Crustacean Monographs 5: 1-387.

Larsen, K., Bird, G. J. and Ota, M. 2013. The ANDEEP Tanaidacea (Crustacea: Peracarida) revisited I: the family Agathotanaidae Lang, with description of four new species. Zootaxa 3630(3): 424444.

Livingston, R. J., Sheridan, P. S., McLane, M. G., Lewis, F. G. III and Kobylinsky, G. G. 1977. The biota of the Apalachicola Bay system: functional relationships. Florida Marine Resources Publications 26: 75-100.

Nagelkerken, I. and Velde, G. 2004a. Are Caribbean mangroves important feeding grounds for juvenile reef fish from adjacent seagrass beds? Marine Ecology Progress Series 274: 143-151.

Nagelkerken, I. and Velde, G. 2004b. Relative importance of interlinked mangroves and seagrass beds as feeding habitats for juvenile reef fish on a Caribbean island. Marine Ecology Progress Series 274: 153-159.

Odum, W. E. and Heald, E. J. 1972. Trophic analysis of an estuarine mangrove community. Bulletin of Marine Science 22: 671-738.

Sieg, J. 1980. Sind die Dikonophora eine polyphyletische Gruppe? Zoologischer Anzeiger 205: 401-416.

Sieg, J. and Heard, R. W. 1983. Tanaidacea (Crustacea: Peracarida) of the Gulf of Mexico. III. On the occurrence of Teleotanais gerlachi Lang, 1956 (Nototanaidae) in the eastern Gulf. Gulf Research Reports 8: 51-62.

Stebbing, T. R. R. 1905. Report on the Isopoda, collected by Professor Herdman at Ceylon in 1902. Ceylon Pearl Oyster Fishery, 1905. Supplementary Reports 23: 1-64.

Tuya, F., Larsen, K. and Platt, V. 2010. Patterns of abundance and assemblage structure of epifauna inhabiting two morphologically different kelp holdfasts. Hydrobiologia 658(1): 373-382. 